\title{
International Risk-Sharing and Optimal Monetary Policy in a Small Commodity-Exporting Economy ${ }^{1}$
}

\author{
Valery Charnavoki, New Economic School \\ vcharnavoki@nes.ru
}

This paper evaluates the welfare implications of alternative monetary policy regimes for a small commodity-exporting economy. In line with the existing literature, welfare analysis shows that a flexible exchange rate regime tends to outperform a fixed nominal exchange rate. However, this paper shows that the welfare costs of a nominal peg vary considerably with the extent of international risk-sharing. In a model with complete and frictionless asset markets, real exchange rate volatility is small, and welfare losses from the nominal peg are negligible. By contrast, under financial autarky, a fixed nominal exchange rate generates significant volatility in inflation and results in large welfare costs. I also consider the welfare properties of flexible regimes, showing that core consumer inflation targeting and non-commodity domestic inflation targeting are not generally optimal, although their welfare costs are small compared to those of a fixed regime. Furthermore, the welfare ranking of these two regimes might depend on the currency in which the tradable goods are priced (producer-currency pricing vs. local-currency pricing).

Keywords: commodity currency, international risksharing, optimal monetary policy, exchange rate regime JEL Codes: E52, F41, Q43
Citation: Charnavoki, V. (2019). International Risk-Sharing and Optimal Monetary Policy in a Small Commodity-Exporting Economy. Russian Journal of Money and Finance, 78(2), pp. 3-27. doi: 10.31477/rjmf.201902.03

\section{Introduction}

It is commonly acknowledged that high volatility in commodity prices affects global economic activity. However, much less attention has been paid to analysing the effect of this volatility on the specific case of small commodity-exporting economies, where primary resources constitute an essential source of export revenues. In these

\footnotetext{
${ }^{1}$ I am grateful to Javier Andrés, José E. Bosca, Antonia Díaz, Juan J. Dolado, Eva Ortega, Loris Rubini, Manuel Santos, and Ludo Visschers for their helpful comments and suggestions.
} 
countries, commodity-price movements have an enormous impact on a wide range of macroeconomic variables, including balance of payments, exchange rates, output and public finance. These effects therefore create serious difficulties for the conduct of macroeconomic policy in such economies.

More specifically, as is stressed in the literature (Chen and Rogoff, 2003; Cashin et al., 2004), real exchange rates in commodity-exporting economies exhibit two salient regularities: (i) they are highly volatile and (ii) they are negatively correlated with world commodity prices. Hence, price hikes affecting basic commodities are usually associated with real exchange rate appreciation and, conversely, price drops are linked to real depreciation. This empirical regularity is known in economic literature as the commodity currency effect, a phenomenon which is illustrated in Figure 1 (see Appendix B) for four developed commodity-exporting countries: Canada, Norway, Australia and New Zealand. ${ }^{2}$

Moreover, the commodity currency effect poses a problem for the conduct of monetary policy in such economies, since fluctuations in the real exchange rate induced by commodity price changes render impossible the simultaneous achievement of stable prices and a stable nominal exchange rate. ${ }^{3}$ Accordingly, there is a trade-off between these two basic goals of monetary policy; the choice of nominal exchange rate regime (flexible vs. fixed) has non-trivial welfare implications. Given that inflation is very costly in an environment with sticky consumer prices, a common suggestion in the open-economy literature is to allow the nominal exchange rate to float freely in these economies, thereby absorbing volatile terms-of-trade shocks (this type of policy recommendation has been made for Canada and Russia in Dib, 2008, and Sosunov and Zamulin, 2007, respectively).

In line with this prescription, many central banks in commodity-exporting economies have adopted the goal of low and stable inflation. For instance, all developed commodity-exporting economies (Australia, Canada, Norway, New Zealand, and Iceland) and many fast-growing emerging economies (Brazil, Chile, and South Africa) pursue an explicit core inflation target, while the nominal exchange rate is allowed to float freely in order to play the role of a shock absorber. There are, however, exceptions to this rule, such as many Gulf oil producers, which peg their currencies to the US dollar, or Nigeria, Iran, and Russia (until 2013), which manage nominal exchange rate fluctuations using

\footnotetext{
${ }^{2}$ Standard deviations for the real commodity price index, real effective exchange rate and their crosscorrelations (for HP-filtered series) for the period 1980Q1-2018Q4 are respectively: 12.4, 3.8 and -0.60 for Canada, 17.5, 2.7 and -0.47 for Norway, 12.0, 6.0 and -0.57 for Australia and 9.2, 5.9 and -0.44 for New Zealand.

${ }^{3}$ Note that the rate of change of the real exchange rate is given (in logs) by $\Delta q_{t}=\Delta e_{t}+\pi_{t}^{*}-\pi_{t}$, where $\Delta e_{t}$ is the rate of change of the nominal exchange rate, and $\pi_{t}$ and $\pi_{t}^{*}$ denote domestic and foreign inflation respectively. Thus, assuming stable foreign prices, fluctuations in the real exchange rate have to be accommodated either by changes in the nominal exchange rate, or by domestic inflation/ deflation.
} 
(partially sterilized) interventions in the foreign exchange markets. The monetary policy authorities in these countries often claim that the main rationale for these operations is to reduce the volatility of the real exchange rate and to reduce the danger of Dutch disease. ${ }^{4}$ Nonetheless, it is often the case that this policy succeeds in smoothing real exchange rate fluctuations, but at the cost of a high (often twodigit) and unstable inflation rate.

In view of these different monetary policy experiences, the goal of this paper is to analyse under which conditions the adoption of a fixed nominal exchange rate might not be such an inadvisable policy per se for small commodityexporting economies. In particular, I argue that the volatility of the real exchange rate and, as a result, the welfare costs of a fixed regime are critically dependent on the extent of risk-sharing between the commodity-exporting economy and the rest of the world. One might intuitively think of two alternative setups. On the one hand, assuming complete and frictionless asset markets, such an economy may be perfectly insured against foreign-commodity shocks, which exert no significant effects on the real exchange rate, rendering welfare losses from a fixed nominal exchange rate negligible. On the other hand, the existence of frictions in international asset trading renders complete insurance against foreign commodity shocks too costly. In such a case, windfall income gains from commodity exports are spent partially at home, and this puts pressure on the real exchange rate, with the result that the welfare costs of the fixed nominal exchange rate regime might be large.

More specifically, to quantitatively analyse the welfare effects of world commodity price shocks under alternative monetary policy regimes, I develop a multi-sector New Keynesian model of a small commodity-exporting economy which can be calibrated to estimate welfare costs in various situations. This model features three production sectors: the primary commodity, non-commodity tradable and nontradable sectors. The world economy is modelled explicitly as in Gali and Monacelli (2005), Catão and Chang (2013) and Charnavoki (2009). Therefore, in contrast to the related literature (for example Dib, 2008, and Sosunov and Zamulin, 2007), world commodity price fluctuations in this model (as well as other global prices and demands) are not treated as shocks per se, but are rather considered to be endogenously determined outcomes (as in Catão and Chang, 2013). This allows me to control directly for the extent of international risk-sharing. The representative households trade a complete set of financial assets, but portfolio pay-offs bear transaction costs. By varying the extent of the financial transaction costs, it is possible to cover

\footnotetext{
${ }^{4}$ Dutch disease is an economic concept that explains the relationship between an increase in export revenues from basic commodities and a decline in the non-commodity tradable sector (mainly manufacturing). The underlying mechanism is as follows. An increase in export of primary commodities will lead to an appreciation in the real exchange rate, making non-commodity exports more expensive. As a result, the manufacturing sector becomes less competitive and its output declines (see Corden, 1984, for more details).
} 
a full spectrum of model economies, ranging from perfect international risksharing to financial autarky. ${ }^{5}$

The formulation of the proposed model takes into consideration several stylized features of primary commodities which have been highlighted in this strand of the literature. First, primary commodities are assumed to be a homogeneous good in the sense that many firms supply goods with similar characteristics and qualities that are traded in organized exchanges or have a reference price (Rauch, 1999). By contrast, tradable and nontradable goods are produced in varieties which differ both between and within countries.

Secondly, while the prices of primary commodities are very flexible (Bils and Klenow, 2004; Gopinath and Rigobon, 2008), there is significant heterogeneity in the frequencies of price changes for manufactured goods and services. ${ }^{6}$ Therefore, nominal prices of primary commodities in the model are assumed to be flexible, whereas price rigidities in the non-commodity tradable and nontradable sectors are modelled using conventional Calvo-Yun contracts. It is also assumed that a certain proportion of prices of exported non-commodity goods is quoted in foreign currency (local-currency pricing, LCP), while the rest is quoted in domestic currency (producer-currency pricing, PCP).

Lastly, output and labour productivity are significantly more volatile in industries producing primary commodities (agriculture, fishing, mining, etc.) than they are in manufacturing, services or construction (see global sector-specific shocks in Koren and Tenreyro, 2007). This can be observed in Table 1 (see Appendix C), which presents, for a sample of OECD countries, the standard deviations for labour productivity in commodity-producing sectors (agriculture, fishing, mining, etc.), as well as in tradable (manufacturing) and nontradable (services, utilities, and

\footnotetext{
${ }^{5}$ Our model is related to the existing theoretical literature studying international risk-sharing, namely Backus-Smith and real exchange rate volatility puzzles, in the context of two-country models. A number of papers explain these puzzles using models with incomplete asset markets. So, e.g., Benigno and Thoenissen (2008) study a model with nontradable and tradable goods sectors. To obtain a negative correlation between relative consumption and the real exchange rate, they assume that productivity shocks to the tradable sector are more persistent and more volatile than those in the nontradable sector. Corsetti et al. (2008) argue that the implied elasticity of substitution between tradable goods is low since nontradable goods are used in the distribution of tradables. This feature allows them to solve Backus-Smith and real exchange rate volatility puzzles in the model with a single traded asset. However, the assumption of incomplete asset markets in the stochastic framework of a small open-economy model results in non-stationary equilibrium dynamics. To induce stationarity, standard models usually assume non-separable preferences or some form of friction in asset trading (Schmitt-Grohe and Uribe, 2003). Yet, these additional elements might resolve the aforementioned puzzles in the framework with complete markets too. For example, Bodenstein (2008) develops a two-country model with complete asset markets and limited enforcement for international financial contracts that provides a possible explanation of these two puzzles. At the same time, Verdelhan (2010) uses habit preferences to explain excess volatility in the real exchange rate.

${ }^{6}$ Bils and Klenow (2004) report that, in the US, $54.3 \%$ of raw goods prices are changed every month compared to $20.5 \%$ of processed goods prices and $20.7 \%$ of service prices. Using US export/import data, Gopinath and Rigobon (2008) estimate the monthly frequencies of price changes at $83 \%$ (73\%) and $30 \%(27 \%)$ for import (export) goods traded on organized exchanges and having reference prices, compared to $7 \%$ (7\%) for differentiated import (export) goods.
} 
construction) sectors. Labour productivity in the commodity sector is on average two and four times more volatile than in the tradable and nontradable sectors respectively. Together with inelastic demand for commodities, this fact could explain excess volatility in commodity prices.

I assume monetary policy in the rest of the world to be conducted in an optimal fashion, and consider four monetary policy regimes for a small commodity-exporting economy: (i) a credible peg of the nominal exchange rate, (ii) targeting core consumer inflation, ${ }^{7}$ (iii) targeting domestic non-commodity output inflation, and (iv) optimal policy with commitment. For the welfare computations, I use a second-order approximation to the welfare and policy functions around the deterministic steady state following the approach advocated by Schmitt-Grohe and Uribe (2004). ${ }^{8}$

The welfare comparisons of the alternative monetary policy regimes are related to existing distortions. In this respect, I abstract away the monopolistic distortion that induces an inefficient level of output by introducing an offsetting subsidy, and instead focus on another two sources of inefficiency to trade off in my model of a small commodity-exporting economy. First, in response to asymmetric disturbances, nominal rigidities create an inefficient dispersion of prices within the tradable and nontradable sectors, as well as an inefficient path for domestic and international relative prices (terms of trade, real exchange rates). Secondly, financial frictions generate a wedge between the marginal utility differential in the home and world economies and the real exchange rate, resulting in demand disequilibria (in the terminology of Corsetti et al., 2010). Furthermore, in the case of LCP, there are deviations from the law of one price, resulting in inefficiency in the supply of tradable goods due to price dispersion in domestic and foreign markets. Finally, as is stressed by many authors (see in particular Corsetti and Pesenti, 2001, and Benigno and Benigno, 2003), there is a strategic element to open-economy monetary policy, since monetary authorities may affect the terms of trade in a way that is beneficial for the domestic economy.

The main findings are as follows. In accordance with the existing literature, the welfare comparisons show that a flexible regime tends to outperform a fixed nominal exchange rate regime. However, the welfare costs of the fixed regime vary significantly with the extent of international risk-sharing and with the size of the home commodity sector. As discussed earlier, assuming complete and frictionless asset markets, welfare losses from the nominal peg are small. Alternatively, if the commodity sector is too small, the home economy cannot generate significant windfall income from commodity exports, meaning that, even under financial autarky, the fixed regime is not very costly. In sum, it is only in the case of a large commodity sector and imperfect financial markets that a fixed regime implies high welfare costs.

\footnotetext{
${ }^{7}$ Note that core consumer price index (CPI) does not include a primary commodity component.

${ }^{8}$ A standard welfare analysis of the open-economy model using second-order approximation to the welfare function but linear approximation to the policy function may produce spurious results (see Kim and Kim, 2003).
} 
This result underscores the practical importance for small commodityexporting economies of adopting cross-country risk-sharing mechanisms of some kind, which would allow them to stabilize their real exchange rates while reducing the welfare costs of keeping the nominal exchange rate pegged. In practice this may be implemented either by hedging in commodity futures markets, ${ }^{9}$ or by creating some form of stabilisation fund, ${ }^{10}$ or even by participating in a full-fledged fiscal union (see Frankel, 2012, for a good review).

Another relevant implication of my analysis is related to the welfare properties of the flexible nominal exchange rate regimes. I show that core consumer inflation targeting and non-commodity domestic inflation targeting are non-optimal in general, though their welfare costs are small compared to those of a fixed regime. Furthermore, the welfare ranking of these two regimes may depend on the currency in which tradable goods are priced (PCP vs. LCP). Given producer-currency pricing, domestic inflation targeting is preferable to core consumer inflation targeting, while the opposite is true given localcurrency pricing.

This rest of the paper is organized as follows. Section 2 presents the main features of the model for a small commodity-exporting economy. Section 3 discusses the calibration of the parameters and shocks. Section 4 reports and discusses the results of simulations: deterministic steady-state, and impulse responses to unitary innovations in foreign commodity shocks, and the principle business cycle statistics. Section 5 measures and discusses the welfare implications of the alternative monetary policy regimes. Finally, Section 6 concludes.

\section{Model}

This section begins by presenting a model of the world economy in a relatively general form. Next, specific assumptions about productivities, commodity endowments and monetary policies are made to reduce this model to the small commodity-exporting economy/world economy case.

Notation is as follows. Variables with a subscript $i$ refer to economy $i$, one among the continuum of economies making up the world economy. Variables without a subscript index $i$ denote the small commodity-exporting economy being modelled. Finally, variables with a superscript star correspond to the world economy as a whole (a typical foreign economy).

\footnotetext{
${ }^{9}$ Believing oil prices would eventually fall, in 2008 Mexico hedged almost all of its oil exports for the next year at prices ranging from USD 70 to USD 100 per barrel at a cost of about USD 1.5 billion through derivatives contracts. According to the Financial Times, this move paid off handsomely, resulting in over USD 5 billion in profit when the price of oil collapsed in 2009.

${ }^{10}$ At the present time, many resource-abundant countries and regions are accumulating part of their commodity revenues in sovereign wealth funds. Examples might be the Government Pension Fund of Norway, the Russian National Wealth Fund, the Alaska Permanent Fund, the Permanent Wyoming Mineral Trust Fund or the Alberta Heritage Fund.
} 


\subsection{General description of the model}

The world economy is modelled as a continuum of small open economies represented by a unit interval, as in Gali and Monacelli (2005). Since each economy is of measure zero, its domestic policy decisions do not have any impact on the rest of the world. I here abstract away monetary frictions and interpret this model as a cashless limiting case (see Woodford, 2003). Asset markets are complete.

A typical small economy produces three types of goods: differentiated tradable goods, differentiated nontradable goods and homogeneous tradable primary commodities. Tradable goods and commodities can be used for consumption either in the domestic economy or abroad, whereas nontradable goods are consumed only in the home country. Firms producing tradable and nontradable goods, as well as commodity endowments, are owned by domestic households.

The world economy is affected by productivity shocks in the tradable and nontradable sectors as well as by shocks to commodity endowments.

\subsection{Households}

A typical small economy $i$ is inhabited by a representative household which owns domestic tradable and nontradable firms and supplies labour to them. This household maximises expected lifetime utility given by:

$$
\begin{gathered}
\max _{\left\{C_{t}(i), L_{N, t}(i), L_{T, t}(i), D_{t+1}\left(i, S_{t+1}\right)\right\}} E_{0} \sum_{t=0}^{\infty} \beta^{t}\left(\frac{C_{t}^{1-\sigma}(i)}{1-\sigma}\right. \\
\left.-X_{N}^{-v}(i) \frac{L_{N, t}^{1+v}(i)}{1+v}-X_{T}^{-v}(i) \frac{L_{T, t}^{1+v}(i)}{1+v}\right)
\end{gathered}
$$

subject to a sequence of budget constraints expressed in terms of domestic currency:

$$
\begin{gathered}
P_{t}(i) C_{t}(i)+\int Q_{t, t+1}\left(i, s_{t+1}\right) D_{t+1}\left(i, s_{t+1}\right) d s_{t+1}+P_{N, t}(i) \Psi\left(\frac{D_{t}(i)}{P_{t}(i)}\right) \\
\leq D_{t}(i)+W_{N, t}(i) L_{N, t}(i)+W_{T, t}(i) L_{T, t}(i)+\Pi_{t}(i)-T_{t}(i)
\end{gathered}
$$

where $C_{t}(i)$ is consumption, $L_{k, t}(i)$ denotes hours worked in sector $k \in\{N, T\}$, $D_{t+1}\left(i, s_{t+1}\right)$ are the holdings of state-contingent claims priced at $Q_{t, t+1}\left(i, s_{t+1}\right)$, paying off one unit of domestic currency in the realised state of the world $s_{t+1}$, $P_{t}(i)$ denotes a consumption price index, $W_{k, t}(i)$ is the nominal wage in sector $k, \Pi_{t}(i)$ denotes profits from the domestic firms and commodity endowment, and $T_{t}(i)$ are lump-sum taxes/transfers. ${ }^{11}$

\footnotetext{
${ }^{11}$ Note that money does not appear in the budget constraint. I here assume that the central bank can directly control the nominal short-run interest rate paid on risk-free assets. Hence, money here functions only as a unit of account.
} 
Note that labour is imperfectly mobile between domestic tradable and nontradable firms. I assign the weights $\chi_{T}(i)$ and $\chi_{N}(i)$ in such a way that wages in both sectors would be equalized in a deterministic steady-state equilibrium.

Given the assumption of complete asset markets, the currency composition of financial assets can be ignored. So, to simplify the notation, only the nominal pay-offs denominated in domestic currency are considered here. The prices of the state-contingent claims paying off in currency $i$ and $j$ are linked as follows:

$$
Q_{t, t+1}(i)=Q_{t, t+1}(j) \frac{\varepsilon_{t}(i, j)}{\varepsilon_{t+1}(i, j)},
$$

where $\varepsilon_{t}(i, j)$ is the bilateral nominal exchange rate (price of currency $j$ in terms of currency $i$ ).

The convex function $\Psi(s)$ reflects the financial intermediation costs which satisfy the following assumptions: $\Psi(s) \geq 0, \Psi(0)=\Psi^{\prime}(0)=0$ and $\Psi^{\prime \prime}(0)=\psi>0$. In particular, I assume quadratic costs: $\Psi(s)=\psi \frac{S^{2}}{2}$. These transaction costs allow us to control risk-sharing between domestic and foreign economies. In the limit, when $\psi \rightarrow \infty$, economy $i$ becomes a financial autarky. Another extreme case, $\psi=0$, corresponds to perfect international risk-sharing. ${ }^{12}$ Without loss of generality, I assume also that these financial intermediation costs are paid in terms of nontradable goods.

The composite consumption good $C_{t}$ is a CES basket of the tradable $C_{T, t}$ and nontradable $C_{N, t}$ goods and commodity $C_{X, t}$ :

$$
C_{t}(i)=\left(\alpha_{T}^{\frac{1}{\epsilon}} C_{T, t}^{\frac{\epsilon-1}{\epsilon}}(i)+\alpha_{N}^{\frac{1}{\epsilon}} C_{N, t}^{\frac{\epsilon-1}{\epsilon}}(i)+\left(1-\alpha_{T}-\alpha_{N}\right)^{\frac{1}{\epsilon}} C_{X, t}^{\frac{\epsilon-1}{\epsilon}}(i)\right)^{\frac{\epsilon}{\epsilon-1}}
$$

where $\epsilon$ denotes the elasticity of substitution between tradable goods, nontradable goods and commodities (gross complementarity is assumed: $\epsilon<1$ ), and $\alpha_{T}$ and $\alpha_{N}$ reflect the weights of tradable and nontradable goods in the composite index.

The index of tradable goods $C_{T, t}$ is in turn a CES basket of home $C_{H, t}$ and foreign $C_{F, t}$ tradable goods:

$$
C_{T, t}(i)=\left(\alpha_{H}^{\frac{1}{\theta}} C_{H, t}^{\frac{\theta-1}{\theta}}(i)+\left(1-\alpha_{H}\right)^{\frac{1}{\theta}} C_{F, t}^{\frac{\theta-1}{\theta}}(i)\right)^{\frac{\theta}{\theta-1}},
$$

where $\theta$ is the elasticity of substitution between home and foreign tradable goods (with $\epsilon<\theta$ ) and $\alpha_{H}$ reflects a home bias in the consumption of tradable goods.

Nontradable, home tradable and foreign tradable indexes, $C_{N, t}, C_{H, t}$ and $C_{F, t}$ respectively, are aggregates of varieties:

\footnotetext{
12 The model of a small open economy with incomplete markets and null transaction costs $(\psi=0)$ is characterized by nonstationary equilibrium dynamics (in contrast to the complete markets case). Nonzero financial intermediation costs may be used to make the price of the debt sensitive to its size and therefore avoid the nonstationarity issue. See Schmitt-Grohe and Uribe (2003) for alternative ways to deal with nonstationarity in the model of a small open economy.
} 


$$
\begin{gathered}
C_{N, t}(i)=\left(\int_{0}^{1} C_{N, t}^{\frac{\eta_{N}-1}{\eta_{N}}}(i, n) d n\right)^{\frac{\eta_{N}}{\eta_{N}-1}}, C_{H, t}(i)=\left(\int_{0}^{1} C_{T, t}^{\frac{\eta_{T}-1}{\eta_{T}}}(i, i, h) d h\right)^{\frac{\eta_{T}}{\eta_{T}-1}}, \\
C_{F, t}(i)=\left(\int_{0, j \neq i}^{1} \int_{0}^{1} C_{T, t}^{\frac{\eta_{T}-1}{\eta_{T}}}(i, j, h) d h d j\right)^{\frac{\eta_{T}}{\eta_{T}-1}}
\end{gathered}
$$

where $C_{N, t}(i, n)$ is the consumption by country $i$ of nontradable variety $n, C_{T, t}(i, j, h)$ is the consumption by country $i$ of tradable variety $h$ produced in country $j$, and $\eta_{N}$ and $\eta_{T}$ are the elasticities of substitution among varieties in nontradable and tradable sectors respectively.

Households allocate their consumption by solving an expenditure minimisation problem (taking prices of goods as given).

\subsection{Firms and commodity endowments}

The markets for tradable and nontradable goods in the model are characterized by monopolistic competition. It is assumed that the only variable factor in production is labour.

Typical firms producing nontradable and tradable goods have the following production functions:

$$
Y_{N, t}(i, n)=A_{N, t}(i) L_{N, t}(i, n), Y_{T, t}(i, h)=A_{T, t}(i) L_{T, t}(i, h),
$$

where $A_{N, t}(i)$ and $A_{T, t}(i)$ are productivity levels in the nontradable and tradable sectors respectively in country $i$, while $L_{N, t}$ and $L_{T, t}$ are labour inputs.

We assume staggered pricing à la Calvo-Yun in the nontradable and tradable sectors (Calvo, 1983). In particular, a fraction $0<\omega_{N}<1$ of the prices of nontradable goods remains unchanged each period, whereas new prices are optimally chosen for the other fraction $1-\omega_{N}$ of nontradable goods.

Since the firms are owned by domestic households, the present value of future profits is discounted according to the household's intertemporal marginal rate of substitution in consumption:

$$
\mathcal{F}_{t, \tau}(i)=\beta^{\tau-t}\left(\frac{C_{\tau}(i)}{C_{t}(i)}\right)^{-\sigma} \frac{P_{t}(i)}{P_{\tau}(i)}
$$

A firm that changes its price in period $t$ chooses $\mathcal{P}_{N, t}(i)$ to maximise the expected discounted stream of profits:

$$
\max _{\left\{\mathcal{P}_{N, t}(i)\right\}} E_{t} \sum_{\tau=t}^{\infty} \omega_{N}^{\tau-t} \mathcal{F}_{t, \tau}(i)\left(\mathcal{P}_{N, t}(i)-\left(1-s_{N}\right) \frac{W_{N, \tau}(i)}{A_{N, \tau}(i)}\right)\left(\frac{\mathcal{P}_{N, t}(i)}{P_{N, \tau}(i)}\right)^{-\eta_{N}} Y_{N, \tau}(i),
$$

where $Y_{N, \tau}(i)=C_{N, \tau}(i)+\frac{1}{2} \psi\left(\frac{D_{\tau}(i)}{P_{\tau}(i)}\right)^{2}$ is aggregate demand for nontradable goods. 
To induce an efficient level of output, government subsidises the firms at a rate $S_{N}$ and finances this subsidy by lump-sum taxes on domestic households. The price index of nontradable goods $P_{N, t}(i)$ is then defined as:

$$
P_{N, t}(i)=\left(\omega_{N} P_{N, t-1}^{1-\eta_{N}}(i)+\left(1-\omega_{N}\right) \mathcal{P}_{N, t}^{1-\eta_{N}}(i)\right)^{\frac{1}{1-\eta_{N}}}
$$

Pricing decisions of the tradable firms are more complicated, given that they can set their prices either in home or in foreign currency. It is assumed here that a share $\gamma$ of all domestic firms in that sector uses PCP. These firms solve the following problem:

$$
\begin{gathered}
\max _{\left\{\mathcal{P}_{T, t}^{P}(i)\right\}} E_{t} \sum_{\tau=t}^{\infty} \omega_{T}^{\tau-t} \mathcal{F}_{t, \tau}(i)\left(\mathcal{P}_{T, t}^{P}(i)-\left(1-s_{T}\right) \frac{W_{T, \tau}(i)}{A_{T, \tau}(i)}\right) \\
\times\left(\left(\frac{\mathcal{P}_{T, t}^{P}(i)}{P_{H, \tau}(i)}\right)^{-\eta_{T}} C_{H, \tau}(i)+\int_{0, j \neq i}^{1}\left(\frac{\mathcal{P}_{T, t}^{P}(i)}{\mathcal{E}_{\tau}(i, j) P_{F, \tau}(j)}\right)^{-\eta_{T}} C_{F, \tau}(j) d j\right),
\end{gathered}
$$

where $s_{T}$ is an offsetting subsidy to tradable firms.

The remaining fraction $1-\gamma$ of domestic tradable firms set their prices using LCP:

$$
\begin{aligned}
& \max _{\left\{\mathcal{P}_{T, t}^{L}(i, j)\right\}_{j}} E_{t} \sum_{\tau=t}^{\infty} \omega_{T}^{\tau-t} \mathcal{F}_{t, \tau}(i)\left\{\left(\mathcal{P}_{T, t}^{L}(i, i)\right.\right.\left.-\left(1-s_{T}\right) \frac{W_{\tau}(i)}{A_{T, \tau}(i)}\right) \\
& \times\left(\frac{\mathcal{P}_{T, t}^{L}(i, i)}{P_{H, \tau}(i)}\right)^{-\eta_{T}} C_{H, \tau}(i)+\int_{0, j \neq i}^{1}\left(\mathcal{E}_{\tau}(i, j) \mathcal{P}_{T, t}^{L}(i, j)-\left(1-s_{T}\right) \frac{W_{\tau}(i)}{A_{T, \tau}(i)}\right) \\
&\left.\times\left(\frac{\mathcal{P}_{T, t}^{L}(i, j)}{P_{F, \tau}(j)}\right)^{-\eta_{T}} C_{F, \tau}(j) d j\right\},(12)
\end{aligned}
$$

where $\mathcal{P}_{T, t}^{L}(i, j)$ are the optimal prices chosen by tradable firms of country $i$ using LCP for their export to country $j$.

The indices of home and foreign tradable goods are then determined by:

$$
\begin{aligned}
P_{H, t}^{1-\eta_{T}}(i)=\omega_{T} P_{H, t-1}^{1-\eta_{T}}(i)+ & \left(1-\omega_{T}\right) \gamma \mathcal{P}_{T, t}^{P 1-\eta_{T}}(i) \\
& +\left(1-\omega_{T}\right)(1-\gamma) \mathcal{P}_{T, t}^{L 1-\eta_{T}}(i, i) \\
P_{F, t}^{1-\eta_{T}}(i)=\omega_{T} P_{F, t-1}^{1-\eta_{T}}(i)+ & \left(1-\omega_{T}\right) \gamma \int_{0, j \neq i}^{1}\left(\varepsilon_{t}(i, j) \mathcal{P}_{T, t}^{P}(j)\right)^{1-\eta_{T}} d j \\
& +\left(1-\omega_{T}\right)(1-\gamma) \int_{0, j \neq i}^{1} \mathcal{P}_{T, t}^{L 1-\eta_{T}}(j, i) d j,
\end{aligned}
$$

where $\mathcal{P}_{T, t}^{P}(j)$ and $\mathcal{P}_{T, t}^{L}(i, j)$ are optimal prices chosen by tradable firms of country $i$ in period $t$ using PCP and LCP respectively. 
For simplicity, it is assumed that output in the commodity sector is exogenously determined and does not involve any costs. Therefore, the profits of this sector are simply the commodity endowment $X_{t}$ times its price $P_{X, t}$ :

$$
\Pi_{X, t}(i)=P_{X, t}(i) X_{t}(i)
$$

\subsection{Governments}

The budget constraint of the government in country $i$ is given by the following equation:

$$
T_{t}(i)=s_{N} W_{N, t}(i) L_{N, t}(i)+s_{T} W_{T, t}(i) L_{T, t}(i),
$$

where $T_{t}(i)$ are lump-sum taxes levied on domestic households to finance offsetting subsidies $s_{k} W_{k, t}(i) L_{k, t}(i)$ to firms in sector $k \in\{T, N\}$.

\subsection{Market clearing conditions}

All goods, factors, and assets markets clear at any time and any contingency.

Market clearing for tradable and nontradable goods and commodities requires:

$$
\begin{array}{r}
Y_{N, t}(i, n)=C_{N, t}(i, n)+\left(\frac{P_{N, t}(i, n)}{P_{N, t}(i)}\right)^{-\eta_{N}} \frac{\psi}{2}\left(\frac{D_{t}(i)}{P_{t}(i)}\right)^{2}, \forall i, n, t \\
Y_{T, t}(i, h)=\int_{0}^{1} C_{T, t}(j, i, h) d j, \forall i, h, t, \int_{0}^{1} X_{t}(i) d i=\int_{0}^{1} C_{X, t}(i) d i, \forall t .
\end{array}
$$

The aggregate supply of labour has to be equal to the aggregate demand for labour in both the nontradable and the tradable sectors:

$$
L_{N, t}(i)=\int_{0}^{1} L_{N, t}(i, n) d n, \forall i, t, L_{T, t}(i)=\int_{0}^{1} L_{T, t}(i, h) d h, \forall i, t .
$$

Finally, the total supply of assets in the world economy is zero at any time and any contingency:

$$
\int_{0}^{1} D_{t}\left(i, s_{t}\right) \varepsilon_{t}(j, i) d i=0, \forall j, t, s_{t} .
$$

\subsection{Productivity and commodity shocks}

So far I have presented a very general model of the world economy. To specify this model for a small commodity-exporting economy/world economy case we need to introduce several assumptions about productivities, commodity endowments, and monetary policy. 
First of all, from among the continuum of small open economies, we choose one economy of measure zero labelled as the home economy. All other (foreign) economies are completely symmetric: they are driven by the same productivities in the nontradable and tradable sectors, $A_{N, t}^{*}$ and $A_{T, t}^{*}$, and commodity endowments, $X_{t}^{*}$. They also share a common currency. As a result, a typical foreign economy represents the world economy as a whole.

The home economy is assumed to be commodity-abundant:

$$
\bar{A}_{N}=\bar{A}_{N}^{*}, \bar{A}_{T}=\bar{A}_{T}^{*}, \bar{X}>\bar{X}^{*},
$$

where $\bar{A}_{T}\left(\bar{A}_{T}^{*}\right), \bar{A}_{N}\left(\bar{A}_{N}^{*}\right)$ and $\bar{X}\left(\bar{X}^{*}\right)$ denote the steady-state productivity of tradable and nontradable firms and commodity endowments in the home and foreign country respectively.

Commodity and productivity shocks in the home and world economies are assumed to follow independent $\mathrm{AR}(1)$ processes:

$$
\begin{aligned}
& \log A_{k, t}=\left(1-\rho_{k}\right) \bar{A}_{k}+\rho_{k} \log A_{k, t-1}+u_{k, t}, k \in\{N, T\} \\
& \log X_{t}=\left(1-\rho_{X}\right) \bar{X}+\rho_{X} \log X_{t-1}+u_{X, t} \\
& \log A_{k, t}^{*}=\left(1-\rho_{k}\right) \bar{A}_{k}^{*}+\rho_{k} \log A_{k, t-1}^{*}+u_{k, t}^{*}, k \in\{N, T\} \\
& \log X_{t}^{*}=\left(1-\rho_{X}\right) \bar{X}^{*}+\rho_{X} \log X_{t-1}^{*}+u_{X, t}^{*},
\end{aligned}
$$

where the disturbance terms $u_{k, t}$ are normally distributed.

\subsection{Monetary policy}

To close the model, we need to specify monetary policy in both the home and the world economies. We assume that all (symmetric) foreign economies share a common currency and that monetary policy in this currency union is conducted in an optimal way, with commitment. Since the home economy is of measure zero, its policy decisions have no effect on the world economy. The world economy is taken as closed and, given that wages and commodity prices are flexible, targeting the weighted index of tradable and nontradable prices gives optimal policy in this economy (see Chapter 6, Section 4.3 in Woodford, 2003; Aoki, 2001). Assuming that the frequencies of price changes and elasticities in the tradable and nontradable sectors are equal, $\omega_{N}=\omega_{T}$ and $\eta_{N}=\eta_{T}$, this weighted index coincides with the core CPI, i.e. the CPI without a commodity component.

I consider four alternative monetary policy regimes for a small commodityexporting economy. The first is a credible fixed nominal exchange rate regime (FER):

$$
\Delta e_{t}=\log \left(\frac{\mathcal{E}_{t}}{\varepsilon_{t-1}}\right)=0, \forall t,
$$

where $\varepsilon_{t}$ is the nominal exchange rate of the home currency. 
The second regime is strict core CPI inflation targeting (CIT):

$$
\pi_{B, t}=\log \left(\frac{P_{B, t}}{P_{B, t-1}}\right)=0, \forall t,
$$

where $P_{B, t}=\left(\frac{\alpha_{N}}{\alpha_{N}+\alpha_{T}} P_{N, t}^{1-\epsilon}+\frac{\alpha_{T}}{\alpha_{N}+\alpha_{T}} P_{T, t}^{1-\epsilon}\right)^{\frac{1}{1-\epsilon}}$ is the core CPI.

The third regime is strict non-commodity domestic output inflation targeting(DIT):

$$
\pi_{D, t}=\log \left(\frac{P_{D, t}}{P_{D, t-1}}\right)=0, \forall t,
$$

where $\pi_{D, t}=\frac{Y_{D, t}^{n}}{Y_{D, t}}$ is the GDP deflator in the tradable and nontradable sectors, with $Y_{D, t}^{n}$ and $Y_{D, t}$ denoting, respectively, nominal and real GDP in these sectors.

Lastly, to characterize an optimal monetary policy with commitment (OP) for the home economy, we need to formulate an infinite-horizon Lagrangian problem where the central bank maximises a conditional expected social welfare function given by:

$$
\mathcal{W}_{t_{0}}=E_{t_{0}} \sum_{t=t_{0}}^{\infty} \beta^{t}\left(\frac{C_{t}^{1-\sigma}}{1-\sigma}-\chi_{N}^{-v} \frac{L_{N, t}^{1+v}}{1+v}-\chi_{T}^{-v} \frac{L_{T, t}^{1+v}}{1+v}\right),
$$

subject to the full set of equilibrium conditions for home and foreign economies for all $t \geq t_{0}$ (implementability constraints) and precommitment constraints for forward-looking variables at $t=t_{0} .{ }^{13}$ Note that optimal policy is conducted in a non-cooperative way. Hence, having monopolistic power over domestic terms of trade, the monetary authority may affect them in a beneficial way for the home economy (see in particular Corsetti and Pesenti, 2001; Benigno and Benigno, 2003).

Appendix A summarizes the equilibrium conditions for the above model of a small commodity-exporting economy/the world economy. Below, basic simulation results and welfare evaluations under the four above-mentioned monetary policy regimes are provided using a calibrated version of the model. However, before moving on to the results, a brief discussion of the model calibration strategy is in order.

\section{Calibration}

This section presents a calibration of the parameters and stochastic shocks for the proposed model of a small commodity-exporting economy. The model is calibrated to quarterly data. Most parameters are standard and their values are taken from the literature. The benchmark calibration is summarized in Table 2 (see Appendix C).

We set the quarterly discount factor $\beta$ equal to 0.99 , which implies an annual steady-state real interest rate of about $4 \%$. The inverse of the intertemporal elasticity

\footnotetext{
${ }^{13}$ I here consider optimal policy from the timeless perspective, as e.g. in Woodford (2011) or Levin et al. (2006).
} 
of substitution, $\sigma$, is fixed at 2 as in most of the literature. ${ }^{14}$ The parameter $v$ plays a dual role in our model: its inverse determines, on the one hand, the Frisch elasticity of labour supply and, on the other, the elasticity of substitution of labour supply across tradable and non-tradable firms. The value of the Frish elasticity is ambiguous, as stressed by Christiano et al. (1997). In most microeconomic studies, it is estimated to be very small, often close to 0 . By contrast, the literature on real business cycles typically works with labour supply elasticities of a much higher magnitude, sometimes in excess of 5. Given the breadth of this range, following Christiano et al. (1997), I use a benchmark value for $v$ equal to 1 , which also corresponds to an estimate of the cross-sectoral elasticity of substitution of labour given by Horvath (2000) and Kim and Kim (2006).

The elasticity of substitution between tradables, nontradables, and commodities, $\epsilon$, is set to 0.74 as in Mendoza (1991). There is some controversy about the value of trade elasticity $\theta$ (see for example Ruhl, 2008, for a good review). The elasticities considered in the literature on international real business cycles range from 0.5 to 2.0. ${ }^{15}$ I use the value 1.5, as in Backus et al. (1992). The elasticities of substitution between varieties in the tradable and nontradable sectors, $\eta_{T}$ and $\eta_{N}$, are set to 11 , which corresponds to price markups equal to $10 \%$. The parameters $\omega_{N}$ and $\omega_{T}$ are set equal to 0.75 , a value consistent with an average period of one year between price adjustments (as in Gali and Monacelli, 2005).

The consumption weights of tradable and nontradable goods, $\alpha_{T}$ and $\alpha_{N}$, are set to 0.4 and 0.5 respectively, which correspond roughly to the weights of non-energy goods and services in the CPI for Canada. The home weight in consumption of tradable goods, $\alpha_{H}$, is equal to 0.5 (according to input-output data for Canada).

Steady-state productivity levels in the tradable and nontradable sectors are assumed to be the same for home and foreign economies: $\bar{A}_{N}=\bar{A}_{N}^{*}=\bar{A}_{T}=\bar{A}_{T}^{*}=1$. Commodity endowment in the world economy, $\bar{X}^{*}$, is also set at 1 . At the same time, three alternative specifications for the home commodity sector are assumed. The first case, $\bar{X}=1$, corresponds to the ex-ante symmetric home economy. In this case there is no international trade in primary commodities in the deterministic steady state. The second alternative, $\bar{X}=4$, corresponds to the chosen benchmark parameterisation of a small commodity-exporting economy. Finally, a model with a large home commodity sector, $\bar{X}=10$, is considered.

To study the effect of financial frictions and international risk-sharing, three variants of the model discussed are given: (i) frictionless asset markets, $\psi=0$; (ii) an intermediate (benchmark) case with $\psi=1$, and (iii) financial autarky with $\psi \rightarrow \infty$. I also consider two alternative pricing regimes for home and foreign tradable firms: PCP, $\gamma=1$, and LCP, $\gamma=0$.

\footnotetext{
${ }^{14}$ See for example Backus et al. (1992).

15 The trade literature works with much higher elasticities ranging from 10 to 15 .
} 
Finally, turning to the parameterisation of exogenous stochastic processes, the persistence parameter, $\rho_{k}$, is set equal to 0.8 for all productivity and commodity shocks. At the same time, the volatilities of nontradable, tradable, and commodity shocks are set to $0.01,0.02$, and 0.04 respectively (for both home and foreign economies). This corresponds roughly to the ratio for OECD countries (see Table 1 in Appendix C). Lastly, productivity and commodity shocks are assumed to be uncorrelated across countries and sectors.

\section{Simulation results}

\subsection{Deterministic steady-state equilibrium}

Discussion of the simulation results may conveniently begin with a brief look at the deterministic steady-state equilibrium. Given the cross-country asymmetry of the model, this equilibrium allows us to identify long-term structural differences between the home and world economies. It is assumed that, in steady state, both economies have balanced trade and zero inflation. ${ }^{16}$ As a result, the corresponding equilibrium depends neither on financial transaction costs $\psi$, nor on the monetary policy regime, nor on the currency of pricing for tradable goods $\gamma$.

A steady-state solution of the model is presented in Table 3 (see Appendix C) given the three alternative assumptions about the steady-state home commodity endowment $\bar{X}$. First, I consider a symmetric case, $\bar{X}=1$, where the home economy is identical to a typical foreign economy. Then I introduce two variants of the commodity-abundant home economy: $\bar{X}=4$ and $\bar{X}=10$.

As expected, the deterministic steady-state allocations and prices in home and foreign economies coincide in the symmetric case. There is no international trade in commodities, while home exports and imports are driven by intra-industry trade in (non-commodity) tradable goods. The steady-state real exchange rate (i.e., the inverse of the international price level) is equal to 1 .

In contrast, the model with a commodity-abundant home economy generates significant asymmetries in the steady state. First, higher commodity endowment makes the home economy wealthier than the foreign one. Households in the home economy enjoy higher welfare, consume more nontradable, tradable, and commodity goods (both in aggregate terms and separately for each type of good), and also work less.

Second, international trade flows fit well with the law of comparative advantages: the home country exports primary commodities, while its imports of foreign tradable goods exceed exports of home tradables. Notice that this steady-

\footnotetext{
${ }^{16}$ An optimal steady state exists in which the inflation rate is zero in our model with optimal monetary policy. I verified this by conjecturing that the solution involves zero inflation, and then determining that the augmented matrix of the system of $N$ equations for $N-1$ Lagrange multipliers has rank equal to $N-1$.
} 
state trade pattern captures an important source of business cycle fluctuations for the small commodity-exporting economy, since world commodity price changes may induce significant windfall incomes (or losses) from commodity exports.

Third, higher demand in the home economy pushes up wages and the prices of nontradable and home tradable goods. At the same time, relative domestic prices of foreign tradable goods and commodities fall. As a result, home consumption of foreign tradable goods increases, whereas foreign consumption of home tradable goods decreases. However, income and substitution effects work in the opposite direction for home demand for home tradable goods. In the case of $\bar{X}=4$, the income effect dominates in steady state, so home consumption of home tradables increases relative to the symmetric variant of the model. Conversely, the substitution effect dominates in the case of a large commodity sector, $\bar{X}=10$. Nevertheless, total demand (home and foreign) for home tradable goods unambiguously decreases. Thus, output and labour in the home economy shift from the tradable to the nontradable sector, reproducing the main feature of socalled Dutch disease.

Lastly, high relative prices for home nontradable and tradable goods result in a higher international price level for the home economy relative to the foreign one (i.e., the steady-state real exchange rate is now lower than 1).

\subsection{Impulse responses}

In this section, I illustrate the dynamic effects of foreign commodity shocks on a number of home macroeconomic variables. I focus here on the benchmark model with intermediate financial transaction costs, $\psi=1$, and an average-sized home commodity sector, $\bar{X}=4 .{ }^{17}$ Figures 2-7 (see Appendix B) display impulse responses to negative unitary innovation in foreign commodity endowment under the four monetary policy regimes.

A reduction in the foreign commodity endowment results in a higher world real commodity price. Moreover, the size of the price increase exceeds the size of the initial commodity shock, since demand for commodities is inelastic (elasticity of substitution between commodity and non-commodity goods $\epsilon$ in my model is less than 1). Both foreign output and consumption fall due to the immediate decrease in the commodity supply and to the induced reduction in demand for nontradable and tradable goods. Since the foreign central bank targets noncommodity consumer price inflation, core inflation does not change. At the same time, headline inflation rises following the increase in the price of its commodity component.

Given that the home economy is a net exporter of commodities in the deterministic steady state, the increase in the world commodity price leads to an

\footnotetext{
17 The model is solved using the Dynare package for MATLAB. The first-order necessary conditions for optimal policy are computed using Andrew T. Levin's code (Levin et al., 2006).
} 
increase in the home trade balance. Non-zero financial transaction costs hinder international risk-sharing between the home and foreign households, so windfall income from commodity exports is partly spent within the home economy. As a result, the real exchange rate appreciates, while demand shifts from commodity and home tradable goods to foreign tradable and home nontradable goods, while labour switches from home tradable to nontradable firms.

Since the prices of tradable and nontradable goods are sticky in the short term, monetary policy can manipulate the real exchange rate (and therefore home and foreign demand) to some extent. Under the PCP regime, nominal exchange rate changes exhibit full pass-through to import prices, and therefore play an expenditure-switching role. A central bank that targets core consumer inflation allows the nominal exchange rate to float freely, absorbing the change in the real exchange rate. Domestic non-commodity output inflation targeting and optimal policy have similar effects. ${ }^{18}$ By contrast, in the case of a fixed nominal exchange rate (and stable foreign consumer prices), the real exchange rate may appreciate only slowly through higher consumer inflation in the home economy. Hence, real exchange rate appreciation is restrained, but at the cost of higher inflation. In other words, monetary policy is too loose in this case, and consumption and output in the home economy are therefore higher than under flexible exchange rate regimes.

Under the LCP regime, the dynamic effects of an increase in commodity prices on the home economy are similar. Yet, since the nominal exchange rate pass-through is zero in this case, the expenditure-switching effect of the nominal exchange rate is impeded. Since adjustment of the trade balance through changes in relative prices is sluggish, the nominal exchange rate must appreciate even more than under PCP to comply with the international risk-sharing condition (A.14 in Appendix A). Given that home tradable firms set their prices in local currency, the nominal appreciation results in higher prices for home tradable goods for the domestic market than for the foreign market. Thus, in contrast to the PCP case, the law of one price fails for these goods. At the same time, the relative price of nontradable vs. tradable consumption goods and the relative price of home vs. foreign tradable consumption goods increase less sharply than in the PCP case, due to home currency pricing of the import goods.

\subsection{Business cycle statistics}

This section is devoted to a brief discussion of the business-cycle properties of some relevant macroeconomic variables under the four monetary policy regimes. I focus on two aspects of business cycles: standard deviations and contemporary

\footnotetext{
18 Since the CPI includes imported consumer goods and, under PCP, their prices are correlated with the nominal exchange rate, core consumer inflation targeting places a higher weight on stabilising the nominal exchange rate than other flexible regimes.
} 
correlations with the real foreign commodity price. These statistics are reported for models with different values of the financial transaction costs parameter, ranging from perfect international risk-sharing, $\psi=0$, to financial autarky, $\psi \rightarrow \infty$. Table 4 in Appendix C and Figure 8 in Appendix B displays these businesscycle statistics generated by foreign commodity shocks alone, whereas Table 5 in Appendix C and Figure 9 in Appendix B illustrate the results for all productivity and commodity shocks.

In the case of perfect international risk-sharing, $\psi=0$, foreign commodity shocks can be perfectly insured against. Hence, the volatility of the real exchange rate induced by these shocks is close to zero and, as result, the standard deviations of core consumer inflation, non-commodity domestic inflation and rate of change of the nominal exchange rate are always small, no matter the monetary policy regime under consideration. The headline consumer inflation volatility is determined exclusively by the growth rate of the price of its commodity component.

Introduction of financial frictions results in reduced volatility in the trade balance, increased volatility in the real exchange rate and a negative correlation between the latter and the real commodity price (the commodity currency effect). Under a flexible nominal exchange rate regime, this obviously translates into higher volatility of the nominal exchange rate. By contrast, a currency peg leads to higher volatility of inflation as well as a positive correlation between inflation and the real commodity price. At the same time, the real exchange rate is, not surprisingly, smoother under a fixed regime, reflecting short-term price stickiness. This effect increases with rising financial costs.

A core consumer inflation targeting regime implies lower volatility of the nominal exchange rate relative to domestic inflation targeting and optimal monetary policy. This result can be explained by the inclusion of import prices in the CPI, and a full pass-through of nominal exchange rate changes into these prices under PCP pricing.

Introduction of other shocks does not alter the results significantly. The only important difference is the non-zero volatility of the real exchange rate in the case of null financial transaction costs, reflecting the impossibility of acquiring insurance against shocks in the nontradable sector as well as the home bias in consumption of tradable goods. Nevertheless, rising financial transaction costs increase real exchange rate volatility and its negative correlation with the real commodity price: as in the previous case, this implies a trade-off between the stability of the nominal exchange rate and inflation.

\section{Welfare analysis}

This section reports the main results of the paper, evaluating the welfare implications of fixed and flexible exchange rate regimes under alternative 
specifications of the model of a small commodity-exporting economy. This welfare analysis focuses on three key parameters.

First, I compare the welfare costs of the exchange rate regimes given three different assumptions about the extent of international risk-sharing (perfect international risk-sharing, $\psi=0$, financial autarky, $\psi \rightarrow \infty$, and an intermediate case, $\psi=1$ ). Second, I analyse the welfare implications of different sizes of home commodity sector. In the first case, the home and foreign economies are completely symmetric ex-ante: $\bar{X}=\bar{X}^{*}=1$. Next, I consider two variants of the commodity-abundant small home economy: $\bar{X}=4$ and $\bar{X}=10$. Finally, I report the results for two variants of the pricing regime for tradable firms: producercurrency pricing, $\gamma=1$, and local-currency pricing, $\gamma=0$.

As before, the above-mentioned four monetary policy regimes are considered (a credible peg of the nominal exchange rate, targeting core consumer inflation, targeting domestic output inflation, and an optimal policy with commitment). Results are reported for two scenarios. The first assumes that the only shock affecting the model economy is a foreign commodity shock. In the second scenario, the model is affected by the full set of home and foreign productivity and commodity shocks.

To evaluate the welfare costs of the alternative monetary policy regimes, second-order approximations of the welfare and policy functions are used (see Schmitt-Grohe and Uribe, 2004). Notice that a standard welfare analysis of the open-economy model using second-order approximation to the welfare function but only a linear approximation to policy function may produce spurious results. For example, Kim and Kim (2003) show that in a simple two-agent economy, this standard method may yield higher welfare under financial autarky than under perfect risk-sharing. The problem is that some key second-order terms of the equilibrium welfare function are omitted. Consequently, the resulting criterion becomes inaccurate to order 2 .

\subsection{Welfare metrics}

I now describe the welfare metric used to evaluate exchange rate regimes. I adopt a procedure proposed by Lucas (1991), whereby unconditional welfare loss is measured in terms of the fraction, $\xi$, of additional deterministic steady-state consumption needed to equate unconditional expected utility under uncertainty with utility obtained under the deterministic steady state:

$$
U\left((1+\xi) \bar{C}, \bar{L}_{N}, \bar{L}_{T}\right)=E\left\{U\left(C_{t}, L_{N, t}, L_{T, t}\right)\right\} .
$$

After taking a second-order approximation of the welfare function, expected utility can be rewritten as: 


$$
\begin{array}{r}
E\left\{U\left(C_{t}, L_{N, t}, L_{T, t}\right)\right\} \approx U\left(\bar{C}, \bar{L}_{N}, \bar{L}_{T}\right)+\bar{C}^{1-\sigma} E\left\{\hat{C}_{t}\right\}+\frac{1-\sigma}{2} \bar{C}^{1-\sigma} \operatorname{Var}\left\{\hat{C}_{t}\right\} \\
-\chi_{N}^{-v} \bar{L}_{N}^{1+v} E\left\{\hat{L}_{N, t}\right\}-\chi_{N}^{-v} \frac{1+v}{2} \bar{L}_{N}^{1+v} \operatorname{Var}\left\{\hat{L}_{N, t}\right\} \\
-\chi_{T}^{-v} \bar{L}_{T}^{1+v} E\left\{\hat{L}_{T, t}\right\}-\chi_{T}^{-v} \frac{1+v}{2} \bar{L}_{T}^{1+v} \operatorname{Var}\left\{\hat{L}_{T, t}\right\},{ }^{(24)}
\end{array}
$$

where $\hat{C}_{t}, \hat{L}_{N, t}$ and $\hat{L}_{T, t}$ denote $(\log )$ deviations of the variables from the deterministic steady state.

Next, the welfare metric, $\xi$, is computed as:

$$
\xi=\left(\left(1+\xi^{m}\right)^{1-\sigma}+\left(1+\xi^{v}\right)^{1-\sigma}-1\right)^{\frac{1}{1-\sigma}}-1,
$$

where $\xi^{v}$ and $\xi^{m}$ denote the parts of welfare costs due to the variance of uncertain consumption and leisure respectively, as well as to the effect of uncertainty on the means of these variables (see Kollmann, 2002). These parameters are defined as:

$$
\begin{gathered}
\xi^{m}=\left(1+(1-\sigma) E\left\{\hat{C}_{t}\right\}-(1-\sigma) \frac{\chi_{N}^{-v} \bar{L}_{N}^{1+v}}{\bar{C}^{1-\sigma}} E\left\{\hat{L}_{N, t}\right\}\right. \\
\left.-(1-\sigma) \frac{\chi_{T}^{-v} \bar{L}_{T}^{1+v}}{\bar{C}^{1-\sigma}} E\left\{\hat{L}_{T, t}\right\}\right)^{\frac{1}{1-\sigma}}-1 \\
\xi^{v}=\left(1+\frac{(1-\sigma)^{2}}{2} \operatorname{Var}\left\{\hat{C}_{t}\right\}-\frac{(1-\sigma)(1+v)}{2} \frac{\chi_{N}^{-v} \bar{L}_{N}^{1+v}}{\bar{C}^{1-\sigma}}\right) \operatorname{Var}\left\{\hat{L}_{N, t}\right\} \\
\left.-\frac{(1-\sigma)(1+v)}{2} \frac{\chi_{T}^{-v} \bar{L}_{T}^{1+v}}{\bar{C}^{1-\sigma}} \operatorname{Var}\left\{\hat{L}_{T, t}\right\}\right)^{\frac{1}{1-\sigma}}-1 .
\end{gathered}
$$

We compute the welfare losses $\xi$ for alternative monetary policy regimes as well as for a natural equilibrium of the model, $\tilde{\xi}$. This natural equilibrium assumes that prices are flexible in the home economy, but sticky in the foreign economy. Thus, equilibrium of the world economy is the same in both the sticky and the flexible variants of the model. In what follows, I report welfare losses in terms of steady-state consumption compared to the natural equilibrium: $\xi-\tilde{\xi}$.

\subsection{Welfare evaluations: foreign commodity shock}

Table 6 (see Appendix C) summarises our welfare evaluations assuming that the only shock in the model is foreign commodity shock. This variant of the model deserves special consideration, given that foreign commodity shocks are the key determinant of commodity price volatility in our model. ${ }^{19}$

\footnotetext{
${ }^{19}$ Since deterministic steady-state equilibrium changes with the size of the home commodity sector, welfare losses are not directly comparable for models with different values of $\bar{X}$. So, for example, a $1 \%$ loss for the model with $\bar{X}=4$ is smaller in absolute terms than a $1 \%$ loss for the model with $\vec{X}=10$.
} 
I begin by discussing the symmetric case: $\bar{X}=\bar{X}^{*}=1$. The simulations show that welfare losses in this variant of the model are negligible irrespective of the monetary policy regime, the extent of international risk-sharing, or the currency of pricing. In this case, the commodity price hike after a negative foreign commodity shock does not induce significant windfall income from commodity export; therefore, even in financial autarky, the real exchange rate appreciates very slightly. As a result, there is no need to change significantly either the rigid nominal prices or the flexible nominal exchange rate regime. In other words, the choice of monetary policy regime is irrelevant in this variant of the model.

The picture changes significantly for a commodity-abundant small economy, however. In this case, windfall income from commodity exports is non-trivial, and the way in which this income is spent has significant implications for real exchange rate volatility. Assuming frictionless asset markets, $\psi=0$, foreign commodity shock is perfectly shared between the home and foreign economies without any effect on the home real exchange rate. Hence, as in the symmetric case, applying one monetary policy regime or another makes no difference in terms of welfare. On the other hand, introducing financial intermediation costs makes complete insurance against foreign commodity shocks suboptimal, and so windfall income from commodity exports is spent partly within the home economy, leading to an appreciation of the real exchange rate. In this case, the choice of monetary policy regime has important welfare implications. Given that nominal prices are rigid and inflation is very costly, flexible exchange rate regimes are preferable to a nominal peg. For example, in the case of an intermediate size of home commodity sector, $\bar{X}=4$, and producer-currency pricing regime, $\gamma=1$, the financial autarky model generates welfare loss of $0.21 \%$ of steady-state consumption with a nominal exchange rate peg compared to a loss of $0.03 \%$ under consumer inflation targeting and $0.02 \%$ under domestic inflation targeting or optimal policy.

A larger size of home commodity sector may significantly increase the welfare costs associated with the fixed nominal exchange rate regime. So, assuming $\bar{X}=10$, the financial autarky model generates a loss of $2.94 \%$ of steadystate consumption for the fixed nominal exchange rate compared to $0.57 \%$ under CPI targeting, $0.07 \%$ under domestic inflation targeting and $0.02 \%$ under optimal monetary policy. ${ }^{20}$ These high welfare costs reflect the increased volatility of the real exchange rate, and as a result the higher volatility of inflation under the fixed nominal exchange rate regime. The model with intermediate financial costs, $\psi=1$, generates a welfare loss of $1.2 \%$ for the nominal peg against $0.16 \%$ under CPI targeting and $0.01 \%$ under either domestic inflation targeting or optimal policy. However, for the model with perfect capital markets, $\psi=0$, welfare costs

\footnotetext{
${ }^{20}$ Given that deterministic steady-state consumption in the model with $\bar{X}=10$ is higher than in the model with $\bar{X}=4$, relatively higher welfare losses in the first case correspond to even higher losses in absolute terms.
} 
are negligible irrespective of the chosen monetary policy regime and the size of the home commodity sector.

The model with local-currency pricing, $\gamma=0$, does not affect the welfare rankings for the fixed nominal exchange rate regime. As before, frictionless financial markets ensure low volatility in the real exchange rate and very small welfare costs for the nominal peg. In contrast, the model with financial frictions and a large home commodity sector yields high welfare losses for this regime. In fact, for a credible fixed exchange rate regime, the currency of pricing does not matter, and the only difference between these two pricing regimes is that under LCP, home and foreign markets are segmented, whereas under PCP the price is the same for both markets. ${ }^{21}$

However, the choice of pricing currency has nontrivial implications for flexible nominal exchange rate regimes. First, LCP contains an additional source of inefficiency due to deviations from the law of one price for prices set to domestic and foreign markets, which lead to distortions in the supply of tradable goods. The volatile nominal exchange rate reveals this inefficiency by generating higher welfare costs for the optimal policy compared to the model with PCP. For example, the financial autarky model with $\bar{X}=10$ yields a welfare loss of $0.27 \%$ for optimal policy under LCP versus a loss of $0.02 \%$ under PCP.

Second, the choice of pricing currency may even change the welfare ranking of the other two flexible nominal exchange rate regimes (targeting core consumer inflation, and targeting non-commodity domestic inflation). So, for example, in the financial autarky model with $\bar{X}=10$, core CPI targeting and domestic inflation targeting regimes have respective welfare losses of $0.57 \%$ and $0.07 \%$ under PCP and $0.27 \%$ and $0.33 \%$ under LCP.

Regarding this last result, it is interesting to note that targeting core consumer inflation yields smaller welfare costs under LCP despite an additional source of inefficiency in this model. To explain this fact, recall that the core CPI index in our model includes nontradable goods, a certain proportion of home tradable goods, and foreign tradable goods. In the financial autarky model, a negative foreign commodity shock results in real exchange rate appreciation and, under core consumer inflation targeting, in nominal exchange rate appreciation. The nominal exchange rate fluctuations exhibit full pass-through into import prices under the PCP regime. Therefore, since the prices of imported goods fall significantly, the monetary authority targeting core CPI inflation must accept an increase in the prices of home tradable and nontradable goods. As a result, domestic inflation has a distortionary effect on output and generates high welfare losses for this monetary policy regime. By contrast, under LCP, the nominal exchange rate passthrough is zero. Therefore, import prices do not fall significantly after nominal appreciation and there is no need to tolerate higher domestic inflation.

${ }^{21}$ The pricing to market has only a second-order effect on price decisions. 


\subsection{Welfare evaluations: all shocks}

I now consider welfare evaluations for the model affected by the full set of home and foreign productivity and endowment shocks. Table 7 (see Appendix C) reports the main results. Though welfare costs in this scenario are higher, the main conclusions are virtually the same as above.

First, the extent of international risk-sharing and the size of the home commodity sector are key factors determining the welfare costs of the fixed nominal exchange rate regime. Though the nominal peg yields higher welfare losses compared to flexible exchange rate regimes for all combinations of parameters, these costs are small under frictionless asset markets, $\psi=0$, and for the model with a small commodity sector, $\bar{X}=1$. In contrast, the financial autarky model with $\bar{X}=10$ generates a huge welfare loss of $4.8 \%$ in terms of steady-state consumption.

Second, the choice of pricing currency has no significant welfare effects for the fixed regime of the nominal exchange rate. Furthermore, targeting core consumer inflation performs worse than targeting non-commodity domestic inflation under PCP, but the ranking of these two regimes changes under LCP.

\section{Conclusion}

In this paper, I have investigated the welfare implications of fixed and flexible exchange rate regimes in a model of a small commodity-exporting economy. I have explicitly modelled the world economy, which allows us to control directly for the extent of international risk-sharing. The model is solved numerically using a second-order approximation to welfare and policy functions in order to accurately reveal the relationship between uncertainty and welfare. The results confirm that, in general, flexible exchange rate regimes have better welfare properties than the nominal peg. However, the welfare costs of the fixed nominal exchange rate vary significantly with the extent of international risk-sharing and the size of the home commodity endowment.

I have also studied alternative flexible nominal exchange rate regimes, and compared their welfare properties to those obtained under an optimal monetary policy with commitment. In particular, I have established that the currency of pricing for imported goods may have important welfare consequences for two targeting regimes: core consumer inflation targeting, and non-commodity domestic inflation targeting. Given the chosen parameterisation, the second regime is preferable to the first in the case of producer-currency pricing, while the inverse is true given localcurrency pricing.

In line with the available literature on this topic, these results emphasise the importance for a small commodity-exporting economy of adopting cross-country risk-sharing mechanisms of some kind. In the absence of this type of mechanism, the welfare costs of uninsured commodity price shocks could be very large for this kind of economy. In practice, cross-country risk-sharing may be achieved by hedging 
in commodity futures markets, creating some form of stabilization fund, or even participating in a full-fledged fiscal union.

Appendices are available at http://rjmf.econs.online/en; dx.doi.org/10.31477/rjmf.201902.03

\section{References}

Aoki, K. (2001). Optimal Monetary Policy Responses to Relative-Price Changes. Journal of Monetary Economics, 48(1), pp. 55-80.

Backus, D. K., Kehoe, P. J. and Kydland, F. E. (1992). International Real Business Cycles. The Journal of Political Economy, 100(4), pp. 745-775.

Benigno, G. and Benigno, P. (2003). Price Stability in Open Economies. Review of Economic Studies, 70(4), pp. 743-764.

Benigno, G. and Thoenissen, C. (2008). Consumption and Real Exchange Rates with Incomplete Markets and Non-Traded Goods. Journal of International Money and Finance, 27(6), pp. 926-948.

Bils, M. and Klenow, P. J. (2004). Some Evidence on the Importance of Sticky Prices. Journal of Political Economy, 112(5), pp. 947-985.

Bodenstein, M. (2008). International Asset Markets and Real Exchange Rate Volatility. Review of Economic Dynamics, 11(3), pp. 688-705.

Calvo, G. A. (1983). Staggered Pricing in a Utility Maximizing Framework. Journal of Monetary Economics, 12(3), pp. 383-398.

Cashin, P., Cespedes, L. F. and Sahay, R. (2004). Commodity Currencies and the Real Exchange Rate. Journal of Development Economics, 75(1), pp. 239-268.

Catão, L. and Chang, R. (2013). Monetary Rules for Commodity Traders. IMF Economic Review, 61(1), pp. 52-91.

Charnavoki, V. (2009). Commodity Price Shocks and Real Business Cycles in a Small Commodity-Exporting Economy. Mimeo.

Chen, Y. and Rogoff, K. (2003). Commodity Currencies. Journal of International Economics, 60(1), pp. 133-160.

Christiano, L. J., Eichenbaum, M. and Evans, C. L. (1997). Sticky Price and Limited Participation Models of Money: A Comparison. European Economic Review, 41(6), pp. 1201-1249.

Corden, W. M. (1984). Booming Sector and Dutch Disease Economics: Survey and Consolidation. Oxford Economic Papers, 36(3), pp. 359-380.

Corsetti, G., Dedola, L. and Leduc, S. (2008). International Risk Sharing and the Transmission of Productivity Shocks. Review of Economic Studies, 75(2), pp. 443-473.

Corsetti, G., Dedola, L. and Leduc, S. (2010). Optimal Monetary Policy in Open Economies. In: B. Friedman and M. Woodford, eds. Handbook of Monetary Economics, ed. 1, Vol. 3. Elsevier, pp. 861-933.

Corsetti, G. and Pesenti, P. (2001). Welfare and Macroeconomic Interdependence. The Quarterly Journal of Economics, 116(2), pp. 421-445. 
Dib, A. (2008). Welfare Effects of Commodity Price and Exchange Rate Volatilities in a Multi-Sector Small Open Economy Model. Bank of Canada Working Paper, N 8.

Frankel, J. A. (2012). The Natural Resource Curse: A Survey of Diagnoses and Some Prescriptions. In: R. Arezki, C. Pattillo, M. Quintyn and M. Zhu, eds. Commodity Price Volatility and Inclusive Growth in Low-Income Countries. Washington, D.C.: International Monetary Fund, pp. 7-34.

Gali, J. and Monacelli, T. (2005). Monetary Policy and Exchange Rate Volatility in a Small Open Economy. Review of Economic Studies, 72(3), pp. 707-734.

Gopinath, G. and Rigobon, R. (2008). Sticky Borders. The Quarterly Journal of Economics, 123(2), pp. 531-575.

Horvath, M. (2000). Sectoral Shocks and Aggregate Fluctuations. Journal of Monetary Economics, 45(1), pp. 69-106.

Kim, J. and Kim, S. H. (2003). Spurious Welfare Reversals in International Business Cycle Models. Journal of International Economics, 60(2), pp. 471-500.

Kim, K. and Kim, Y. S. (2006). How Important is the Intermediate Input Channel in Explaining Sectoral Employment Comovement over the Business Cycle? Review of Economic Dynamics, 9(4), pp. 659-682.

Kollmann, R. (2002). Monetary Policy Rules in the Open Economy: Effects on Welfare and Business Cycles. Journal of Monetary Economics, 49(5), pp. 989-1015.

Koren, M. and Tenreyro, S. (2007). Volatility and Development. The Quarterly Journal of Economics, 122(1), pp. 243-287.

Levin, A. T., Onatski, A., Williams, J. and Williams, N. M. (2006). Monetary Policy Under Uncertainty in Micro-Founded Macroeconometric Models. NBER Macroeconomics Annual, 20, pp. 229-287.

Lucas, R. E. (1991). Models of Business Cycles. Wiley-Blackwell.

Mendoza, E. (1991). Real Business Cycles in a Small Open Economy. American Economic Review, 81(4), pp. 797-818.

Rauch, J. E. (1999). Networks versus Markets in International Trade. Journal of International Economics, 48(1), pp. 7-35.

Ruhl, K. J. (2008). The International Elasticity Puzzle. Mimeo

Schmitt-Grohe, S. and Uribe, M. (2003). Closing Small Open Economy Models. Journal of International Economics, 61(1), pp. 163-185.

Schmitt-Grohe, S. and Uribe, M. (2004). Solving Dynamic General Equilibrium Models Using a Second-Order Approximation to the Policy Function. Journal of Economic Dynamics and Control, 28(4), pp. 755-775.

Sosunov, K. and Zamulin, O. (2007). Monetary Policy in an Economy Sick with Dutch Disease. CEFIR/NES Working Paper Series, N 101.

Verdelhan, A. (2010). A Habit-based Explanation of the Exchange Rate Risk Premium. Journal of Finance, 65(1), pp. 123-146.

Woodford, M. (2003). Interest and Prices: Foundations of a Theory of Monetary Policy. Princeton University Press.

Woodford, M. (2011). Optimal Monetary Stabilization Policy. In: B. Friedman and M. Woodford, eds. Handbook of Monetary Economics, Vol. 3B. Amsterdam: Elsevier, pp. 723-828. 